\title{
The adherence of the diet to Mediterranean principle and its impacts on human and environmental health
}

\author{
De Marco Alessandra ${ }^{1}{ }^{\text {* }}$, Velardi Maria ${ }^{1}$, Camporeale Cecilia ${ }^{1}$, Screpanti Augusto ${ }^{1}$, \\ Vitale Marcello ${ }^{2}$ \\ ${ }^{1}$ Italian National Agency for New Technologies, Energy and sustainable economic development (ENEA), C.R. Casaccia, Via \\ Anguillarese 301, Rome, Italy \\ ${ }^{2}$ Department of Environmental Biology, Sapienza University of Rome, Rome, Italy
}

\section{Email address:}

alessandra.demarco@enea.it (De M. Alessandra), maria.velardi@enea.it (V. Maria), cecilia.camporeale@enea.it (C. Camporeale), augusto.screpanti@enea.it (S. Augusto), marcello.vitale@uniroma1.it (V. Marcello)

\section{To cite this article:}

De Marco Alessandra, Velardi Maria, Camporeale Cecilia, Screpanti Augusto, Vitale Marcello. The Adherence of the Diet to Mediterranean Principle and Its Impacts on Human and Environmental Health. International Journal of Environmental Protection and Policy. Vol. 2, No. 2, 2014, pp. 64-75. doi: 10.11648/j.ijepp.20140202.14

\begin{abstract}
The Mediterranean Adequacy Index (MAI) trends from 1961to 2007, for 48 countries pooled in 4 clusters according to their geographical location (Mediterranean European (ME) countries, Other Mediterranean (OM) countries, Northern European (NE) countries, Eastern European (EE) countries), has been analysed. In almost all the countries the adherence to Mediterranean diet is decreasing from 1961up to 2007, even if with different trend linked to the geographical and cultural characteristic of the clusters (respectively $-56 \%$ for European Mediterranean and -21 for non-European Mediterranean). The cluster more adherent to healthy Mediterranean diet principles is the OM one, where the incidence of colorectal cancer is shown to be around 50\% lower respect to the incidence in ME countries, and around 60\% lower respect to the incidence in EE and NE countries. A significant relationship was observed between colorectal cancer incidence and animal protein consumption. On the other hand, vegetable protein intake is suggested to be slightly protective against colorectal cancer incidence. The ecological footprint of food production is higher in ME and NE than in OM and EE countries, even if it is generally higher than the biocapacity. In the $70 \%$ of the analysed countries water consumption for food production exceeds the total water exploitable, with an increasing trend from 1961 to 2007. An increase of 1 unit of MAI can decrease the ecological, carbon and water footprint (around 20-25\%), in dependence on the initial level of MAI. Due to the environmental and health beneficial effects, the Mediterranean diet can be promoted as a win-win diet system.
\end{abstract}

Keywords: Mediterranean Adequacy Index, Protein Intake, Food Ecological Footprint, Food Carbon Footprint, Food Water Footprint

\section{Introduction}

The Mediterranean diet has been recently inscribed on the Representative List of the Intangible Cultural Heritage of Humanity (Reguant 2009). The latter was the consequence of a multilateral framework for ingoing dialogue and cooperation between the EU and its Mediterranean partners (Dernini 2006). Several papers carried out over the last three decades reported that Mediterranean diet met numerous important criteria for a healthy diet (Keys 1980; Trichopoulou et al. 1995; Osler and Schroll 1997; Kouris-Blazos et al. 1999; Corbalan et al. 2009), focussing on protein consumption and its effects on health (Westhoek et al. 2011).Different Mediterranean-style diets were shown as an important strategy for prevention and treatment of the metabolic diseases (Kastorini et al. 2011), and for reduction of cardiovascular risks (Esposito et al. 2006; Goulet et al. 2007; Toobert et al. 2007; Buckland et al. 2008; Lazarou 2009). Moreover, a promotion of eating habits, much more associated to the typical Mediterranean diet, may be effective in combating obesity (Corbalan et al. 2009, Mendez et al. 2006; Panagiotakos 2006) and glycaemic-based diseases (Shai et al. 2008). The Mediterranean diet is constituted by olive oil, olives, cereals (beer is excluded from the cereal group), starchy roots, fruits (except wine grapes), vegetables, nuts, fish and seafood, legumes and wine (Alberti-Fidanza et al. 1999). On the other hand, non-Mediterranean food is constituted 
by other sources of fat, sugar and sweeteners, alcoholic beverages (except wine and beer), meats, offal, animal fat and miscellaneous products, beer, sugar crops, oil crops. Cheese is generally included in non-Mediterranean food, except for some case like feta cheese in Greece (Chrysohoou et al. 2004).Adherence to a Mediterranean diet was defined through scores that estimated the conformity of the dietary pattern of the studied population with the traditional Mediterranean dietary pattern (Sofi et al., 2008). The adherence to the Mediterranean diet can be calculated by the Mediterranean Adequacy Index (MAI), which is defined as the ratio between energy provided by Mediterranean and Non-Mediterranean food (AlbertiFidanza et al. 1999; Alberti-Fidanza and Fidanza 2004; Alberti et al. 2009). As a consequence, high values of MAI determine high adherence of alimentary habits to the Mediterranean dietary.

It is worth to note that dietary habits can also affect the functional status of the environment, other than human health. Consequences of a sustainable food production and consumption in the reduction of the greenhouse gases emissions, water consumption and ecological footprint have been analysed in the last decades. Galli et al. (2012) defined a 'Footprint Family' of three of the most wellrecognized footprints, for assessment of the three environmental issues mentioned above. The 'Footprint Family' included the carbon footprint (CF), the Ecological Footprint (EF), and the water footprint (WF).The ecological footprint $(\mathrm{EF})$ has frequently been mentioned as one of the indicators that could be used in this context. EF is defined as the total amount of ecologically productive land required to support the consumption of a given population in a sustainable way(Rees, 1992; Wackernagel and Rees, 1996). Tightly linked to EF is the biocapacity, which is defined as the ability of a given biologically productive area to generate an on-going supply of renewable resources and to absorb its spill over wastes. Ecological Footprint and biocapacity values are expressed in mutually exclusive units of area necessary to annually provide (or regenerate) such ecosystem services: cropland for the provision of plant-based food and fibre products; grazing land and cropland for animal products; fishing grounds (marine and inland) for fish products; forests for timber and other forest products; uptake land to accommodate for the absorption of anthropogenic carbon dioxide emissions (carbon Footprint); and built-up areas for shelter and other infrastructure (Borucke et al, 2013). As a consequence, when EF is exceeding the bio-capacity of an area then the unsustainability is occurring.

The carbon footprint is a measure of the impact that human activities have on the environment in terms of the amount of greenhouse gases produced, measured in tonnes of carbon dioxide (ETAP, 2007). The water footprint is indeed an indicator of freshwater use that looks not only at direct water use of a consumer or producer, but also at the indirect water use. The water footprint can be regarded as a comprehensive indicator of freshwater resources appropriation, next to the traditional and restricted measure of water withdrawal. The water footprint of a product is the volume of freshwater used to produce it, and measured over the full supply chain (Hoekstra, 2003).

Anthropogenic emissions of greenhouse gases (GHGs) related to food production accounts for about $15 \%$ at global level. Food choices and diet can drastically influence the GHG emissions and meals with similar caloric intake may differ in GHG emissions by a factor lasting from 2 to 9 (Carlsson-Kanyama 1998; Carlsson-Kanyama et al. 2003; Engstrom et al. 2007). Mekonnen and Hoekstra (2011) reported that about $92 \%$ of water footprint is associated to the consumption of agricultural products at global level. Finally, Duchin (2005), in a comparative study concerning the sustainability of different diets, argued that a predominantly vegetable-based Mediterranean-type diet had a lower environmental impact than the current average US diet. Aim of this paper is to explore the potentialities of the Mediterranean Adequacy Index (MAI) as a tool characterising impacts on human health and environment, in the frame of different diet habits of forty-eight European and non-European countries, some of which looking out at Mediterranean basin. This analysis will take into consideration a time range lasting from 1961 to 2007, according to FAO database and benefits of a Mediterranean-type diet on cancer incidence and on carbon, water and ecological footprints will be discussed.

\section{Methods}

\subsection{Data Collection}

Forty-eight countries representing different geographic locations and diet habits were selected in order to constitute a large data set for statistical analyses. In this study, countries have been pooled into four clusters according to their geographical location, as follows: Mediterranean Europe(ME), Northern Europe(NE), Eastern Europe (EE)and other Mediterranean (OM) countries (Table 1).

Food consumption data per commodity were achieved from the Food and Agriculture Organization (FAO, 2011) food balance sheets (years 1961-2007), where the data were reported in terms of food production and trade and supply per commodity, as total amount or per capita, for each considered country.

Concerning cancer incidence per country we examined the colon-rectal cancer incidence data, in fact colorectal cancer is the cancer more directly linked to the diet; the data were supplied by the GLOBOCAN project (WHO 2008).

Data for elaboration of the total ecological footprint derived from the Global Footprint Network, database (GFN, 2011), whereas data concerning the exploitable water for all considered countries were supplied by the Aquastat database (AQUASTAT, 2011) that is a FAO's global information system on water and agriculture, developed by the Land and Water Division. Finally, data about the total 
carbon footprint per country were achieved from Carbon Planet database (IEA, 2009)

\subsection{Mediterranean Adequacy Index}

Food commodities consumption data from 1961 to 2007 were partitioned between Mediterranean and nonMediterranean food, in according to the methodology described by Alberti-Fidanza and Fidanza (2004) for calculating the Mediterranean Adequacy Index (MAI).

\subsection{Ecological, Water and Carbon Footprints}

Ecological Footprint (total hectares per capita per year), Water Footprint $\left(\mathrm{Gm}^{3}\right.$ per capita per year) and Carbon Footprint (tonnes of $\mathrm{CO}_{2}$ equivalent per capita per year) were calculated for each country during the 1961-2007 years, taking into consideration either food production or food consumption. The Ecological Footprint uses yields of primary products (from cropland, forest, grazing land and fisheries) to calculate the area necessary to support a given activity (Borucke et al, 2013; Wiedmann \& Barrett, 2010; Wiedmann \& Lenzen, 2007; Wackernagel et al., 2004; Wackernagel \& Yount, 1998). The Carbon Footprint is defined as a measure of the exclusive total amount of carbon dioxide emissions that is directly and indirectly caused by an activity or is accumulated over the life stages of a product (Wiedmann \& Minx 2008).The Water Footprint of an individual, community or business is defined as the total volume of freshwater that is used to produce the goods and services consumed by the individual or community or produced by the business (Hoekstra et al., 2011). At aiming to calculate all these footprints (water, carbon and ecological) for each commodity it was applied an invariant specific factor for each country, according to the literature (Collins and Fairchild 2007; Schlich and Fleissner 2005; Buchner et al. 2009). Two different factors were applied: one for food consumption (relative to cooked or crude commodities) and the other for food production (Buchner et al. 2009).

\subsection{Statistical Analyses}

Descriptive statistics and one-way ANOVA have been carried out by using the four countries clusters as grouping factor. The Newman-Keuls test has been used for the posthoc tests in the ANOVA analysis, and performed at $\mathrm{p}<0.05$ of significance level.

\subsection{GIS Analysis}

The spatial representation was performed using the open source DIVA Geographic Information System (GIS) (www.divagis-org)

\section{Results}

\subsection{Mediterranean Adequacy Index (MAI)}

The Mediterranean adequacy index (MAI) was calculated based on the main commodities consumption in terms of calories per capita (Fig. 1), and repartitioned for the four clusters described in Table 1. It was remarkable that European Mediterranean countries increased their dairy and meat consumptions but reduced olive oil and pulses in the diet during the 1961-2007 time period (Fig. 1). Northern Europe countries, in turn, showed a marked reduction of fats consumption, although total meat consumption remained high and olive oil consumption was very low. However, the non-European Mediterranean countries showed a progressive enhancement of consumption of almost all commodities excepted for olive oil, suggesting a change in traditional diet habits (Fig. 1).

The MAI has been calculated for each country in the frame of the 1961-2007 time period (Figs. 2A-C). Looking at maps of figure 2 ( $\mathrm{A}$ and $\mathrm{B}$ ) it was evident a change in the diet habits of the countries, underlined by difference in the MAI values between 1961 (Fig. 2A) and 2007 (Fig. 2B), where for great part of the countries a reduction of the MAI it was observed. The temporal trend of the MAI followed a progressive reduction of values (Fig. 2C), which were much more evident for European Mediterranean countries $(-56 \%)$ and for Eastern Europe ones (-59\%). Furthermore, non-European Mediterranean countries showed the reduction of the MAI's values $(-21 \%)$, although they had overall higher values than European countries showing that dietary their habits are more adherent to the Mediterranean style diet. Northern Europe countries showed a MAI values around one (Fig. 2C) which pointed out, as expected, their distance from a typical Mediterranean diet. The differences of MAI among country clusters were supported by the analysis of variance (ANOVA) where the average MAI value calculated for European Mediterranean countries $(1.41 \pm 0.42)$ was significantly different with respect to nonEuropean Mediterranean countries (2.91 \pm 0.93$)$ and Northern Europe $(0.88 \pm 0.14)$, but it was not significant from the Eastern Europe (1.29 \pm 0.18$)$.

\subsection{Epidemiological Effects of Protein Intake}

The overall reduction of MAI was caused by an increase in the meat consumption as previously highlighted in the Figure 1. Interestingly, it was not observed significant relationship between protein intake per capita and the colorectal cancer (data not shown). However, if protein intake was partitioned into animal and vegetable-originated proteins a very different distribution was observed among considered countries (Fig 3A and B). In fact, similarly to the case of MAI, the distribution of animal or vegetable protein intake followed a latitudinal gradient. The animal protein intake was increasing from Southern to Northern Europe, whereas vegetal protein intake showed a reverse trend. Moreover, it was evident a positive and significant relationship $(\mathrm{r}=0.61, \mathrm{p}<0.01)$ between colorectal cancer incidence and animal protein intake per capita (Fig. 3C), but not with vegetable protein intake (Fig. 3D). Furthermore, evidence concerning the linkage between meat consumption and incidence risk of the colorectal 
cancer came from geographical distribution of these variables (Fig. 4A and $\mathrm{B}$, respectively). The close-fitting relationship between bovine meat consumption and incidence risk of colorectal cancer was quantified throughout the figure $4 \mathrm{C}$, where a significant linear correlation was found $(\mathrm{r}=0.464, \mathrm{p}<0.01)$. Moreover, the

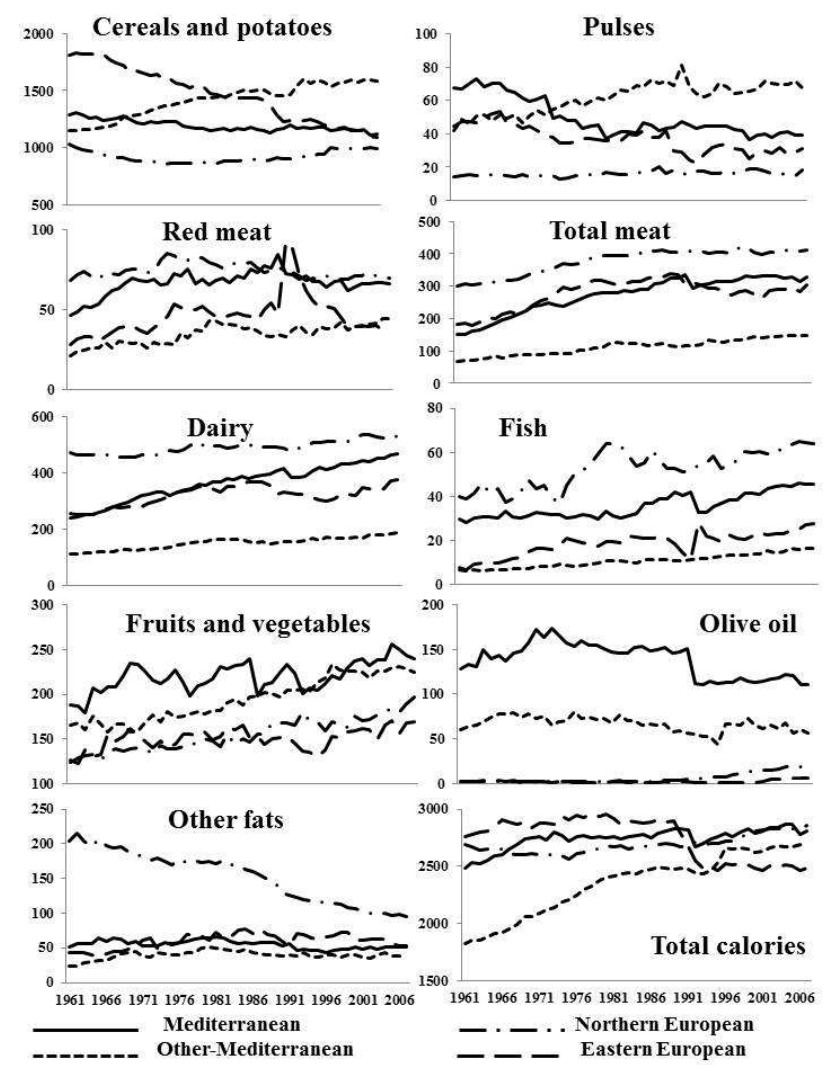

Fig 1. Trend of commodities consumption. Trend of the main commodities consumption in terms of calories per capita for Mediterranean countries (continuous line), other-Mediterranean countries (dotted line), Northern European countries (dotted-dashed line), eastern Mediterranean countries (dashed line) from the year 1961 to 2007.

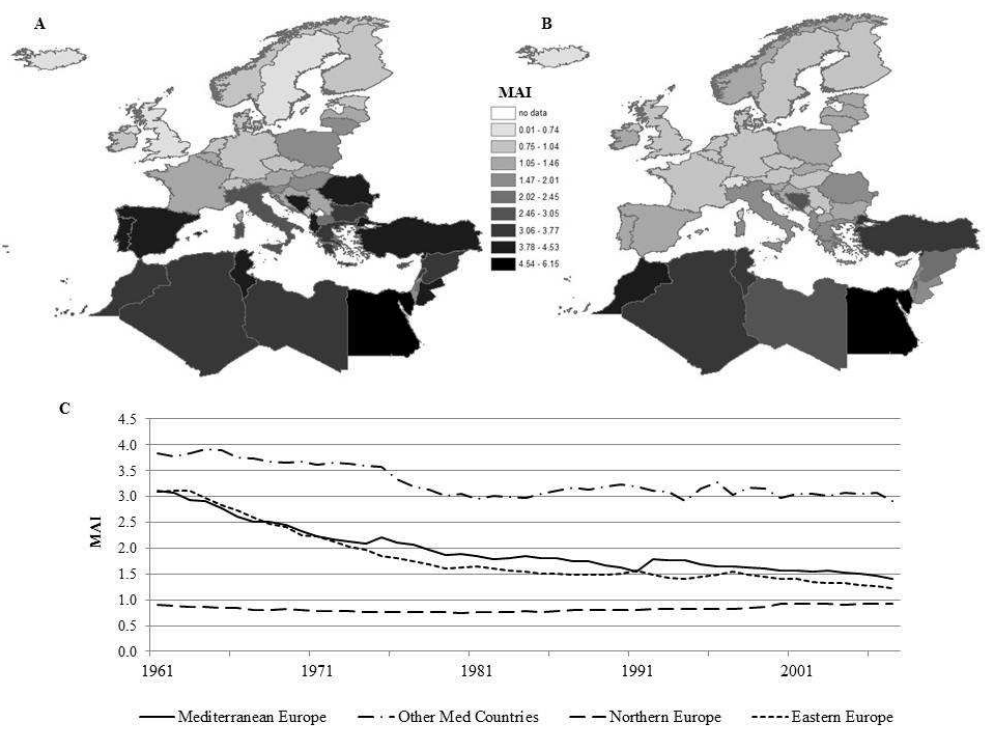

Figure 2. Mediterranean Adequacy Index (MAI) trend. The figure shows Mediterranean Adequacy Index (MAI) for all the countries considered in the two referring years: 1961 (A) and 2007 (B). Panel C shows the MAI trend for the 4 clusters Mediterranean European (ME) countries (solid line), Other Mediterranean (OM) countries (dot-dashed line), Eastern European (EE) countries (dotted line) and Northern European (NE) countries (dashed line).

inverse relationship between MAI and colorectal cancer was significant $(\mathrm{r}=-0.67, \mathrm{p}<0.01)$, suggesting thus the importance of the MAI for defining health status of a country by adherence of diet habits to the Mediterranean diet. 


\subsection{Environmental Impacts of Food}

For each country the total ecological footprint for food production and consumption for the 2006 calculated by sum of each commodity footprints. Non-European Mediterranean countries had a smaller ecological footprint if compared to all the other European countries (Fig. 5B). Moreover, food production and consumption footprints represented the great part of the total ecological footprint, except for Israel, which showed to be similar to the Mediterranean European countries (Fig. 5A). It is noteworthy that total ecological footprint was overcoming the biocapacity of all countries, except for Sweden and Finland among northern European countries (Fig. 5C) and Latvia and Estonia among eastern Europe ones (Fig. 5D). Jordan, Israel, Egypt, Italy, Portugal and The Netherlands showed the food consumption footprint higher than their biocapacity. Denmark, Norway and France demonstrated a food production footprint higher than the food consumption one, due to the respective economic vocation (i.e. Denmark and France were meat exporters). Moreover, the temporal trend (1961-2006) of the food production ecological footprint was increasing for all countries, although with different rates (not shown data).These aspects being well related to the food production and consumption involved a greater impact on the environmental resources rather than epidemiologic evidences.

Testing for MAI as useful indicator pointing out ecological, carbon and water footprints, it was evident a clear relationship among them (Fig. 6A-C). Ecological footprint was well related to MAI by a power function showing a decreasing trend (Fig. 6A); it was clear that countries characterised by low values of MAI exerted a great impact on environmental resources. Similarly, carbon (Fig. 6B) and water (Fig. 6C) footprints was high for countries with low values of MAI. This suggested that Mediterranean diet was the more appropriate for a sustainable use of natural resources. A measure of possible reduction that can be obtained for environment protection is summarized in table 2. Lower is the starting level of MAI for a specific country, higher is the reduction that can be achieved increasing 1 unit of MAI.

Finally, food production or consumption water footprints and total exploitable water ratio were calculated only for countries where exploitable water data were available (Fig. 7). Only Norway, Austria, Switzerland, Albania, Luxembourg, Ireland, Greece have a ratio between water consumption for both food production and consumption lower than the total exploitable water. This value range between $4 \%$ in Norway to 800 percent in Denmark. This ratio highlights that many of the countries considered use more water than the total water exploitable. Only Norway has a huge amount of exploitable water compared to its food production and consumption needs.

\section{Discussion}

During the last 40 years a drastic change in the commodities consumption was observed (Fig. 1) in terms of quantity and quality, as the result of changes in agricultural practices also (van Meijl et al., 2006), which has increased the capacity to provide food for people through increasing productivity and less seasonal dependence. In particular, meat and fish consumption increased in all the clusters, as well as fruits and vegetable consumption. EE countries increased meat consumption, with a respective decrease of cereals and potatoes. Interestingly is the "europeization" of total calories consumption of OM countries, that reach levels close to the other clusters. Food availability has also increased as a consequence of the rising of income levels (Kerney, 2010). In general, actual protein consumption were well above the level suggested by WHO for health protection, set to 18.5 $\mathrm{kg} /$ year/capita (WHO, 2008).This change in dietary habits leads to the observed trends in figure 2 that shows the systematic decrease in the MAI values for all the Mediterranean European or not European countries, including the eastern ones. This phenomenon is reflecting the different food behaviours in the different clusters of countries. As already reported (Bates et al., 2011) the diet of the population fails to meet dietary recommendations by exceeding the maximum recommendations for saturated fatty acids, added sugars (i.e. non-milk extrinsic sugars), and sodium and failing to achieve minimum recommendations for fibres. We suggest that the guidelines for protein intake (based on total protein intake concept),recommended by WHO, should be re-considered in relation to the findings underlining the significant relationship between animal protein intake and colorectal cancer incidence (Fig. 3A), whilst a not significant relationship was found if vegetable protein intake was considered (Fig. 3B). In fact, it is important to underline that vegetable protein intake could be counteract negative impacts of animal protein consumption, as carried out by recent finding of Figueiredo et al., in press. The relationship between red meat consumption and colorectal cancer incidence supported the evidences that dietary habits are strongly impacting on human health (Larsson and Wolk 2006; Gingras and Béliveau 2011; Chan et al. 2011). Beneficial impact of dietary habits were suggested and demonstrated in the last 15 years (Boganiet al. 2007; Rotondi and Lapucci 2010; Owen et al. 2000; Galeone et al. 2006, Sofi et al., 2008). The study from Macdiarmid et al (2012) has shown that changing food choices to meet dietary requirements for health could also help toward mitigating climate change. However, it cannot be assumed that all diets that meet the dietary requirements for health will necessarily have lower greenhouse gases emissions (GHGE); it is equally possible to create a healthy diet by using a different combination of foods that has a high 
GHGE. Our results, on the other hand, support the consideration that Mediterranean diet is in the same time healthy for its beneficial impacts on colorectal cancer incidence, and associated with lower GHGE. This consideration is confirmed by results observed in figure 6 and summarized in table 2. An increase of 1 unit of MAI at low level (MAI from 1 to 2) lead to a reduction of ecological, carbon and water footprint of 23, 17, and $24 \%$,respectively. Thus a MAI increase can be effective on environment health, and the beneficial effects can be higher in non-Mediterranean countries where the MAI levels are low.
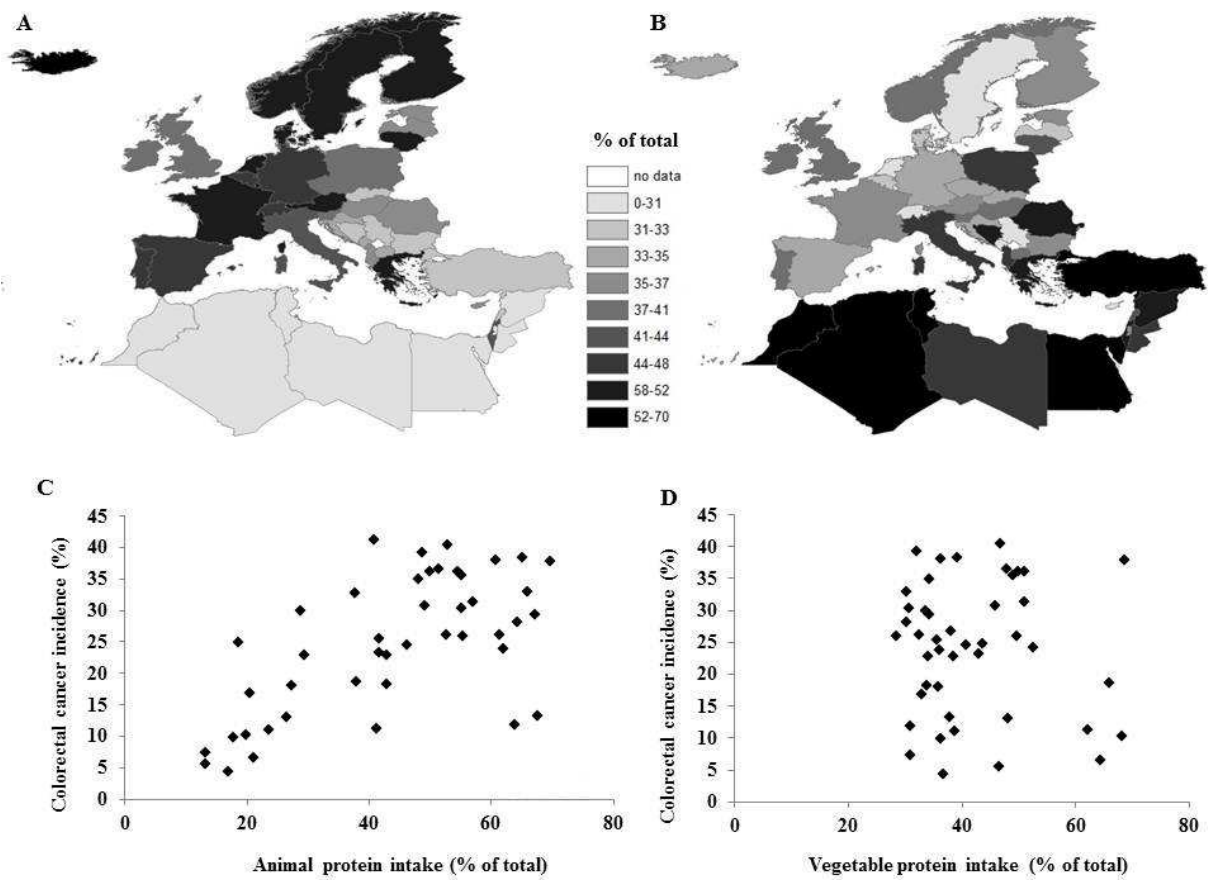

Figure 3. Protein intake and its epidemiological effects. Panel A and B show respectively animal and vegetal protein intake for the different countries, expressed like percentage of the total protein intake. Panel $C$ shows the relationship between animal protein intake and colorectal cancer incidence ( $p<0.05)$. Panel D shows the relationship between vegetal protein intake and colorectal cancer incidence. Points of the graph are the correlation between protein intake and incidence of colon cancer per country.

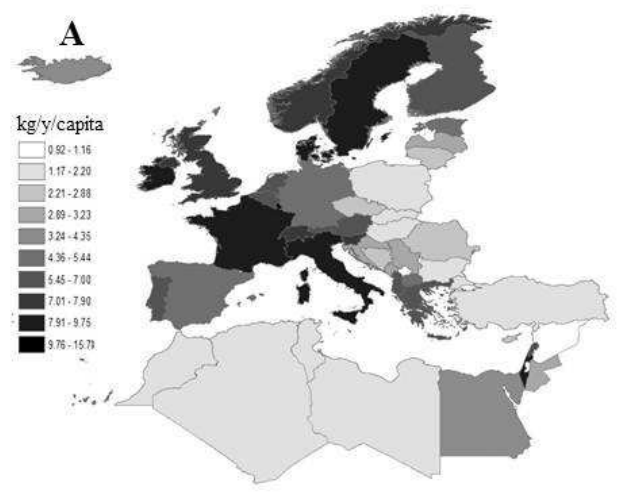

C

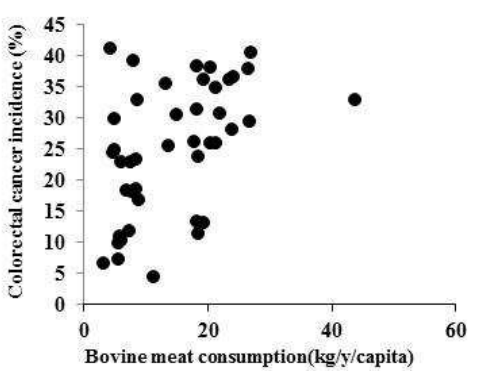

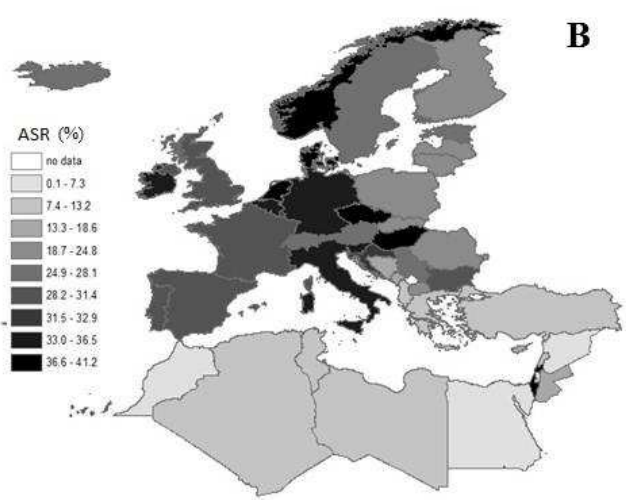

D

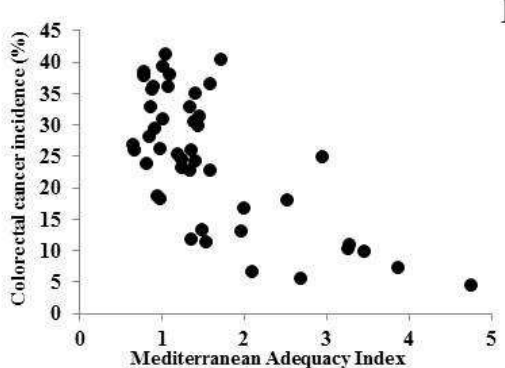

Figure 4. Red meat supply and its incidence on colorectal cancer. Panel A shows the red meat supply map for the selected countries with a growing black colour corresponding to high level of red meat consumption, while panel B illustrates colorectal cancer incidence expressed like percentage. The two maps are for the year 2007. The correlation between the colorectal cancer incidence and red meat supply is shown in Panel C, while Paned D shows the 
correlation between MAI and colorectal cancer incidence in terms of Age-Standardized Rate (ASR). The two graphs show relationship statistically significant $(p<0.01)$.
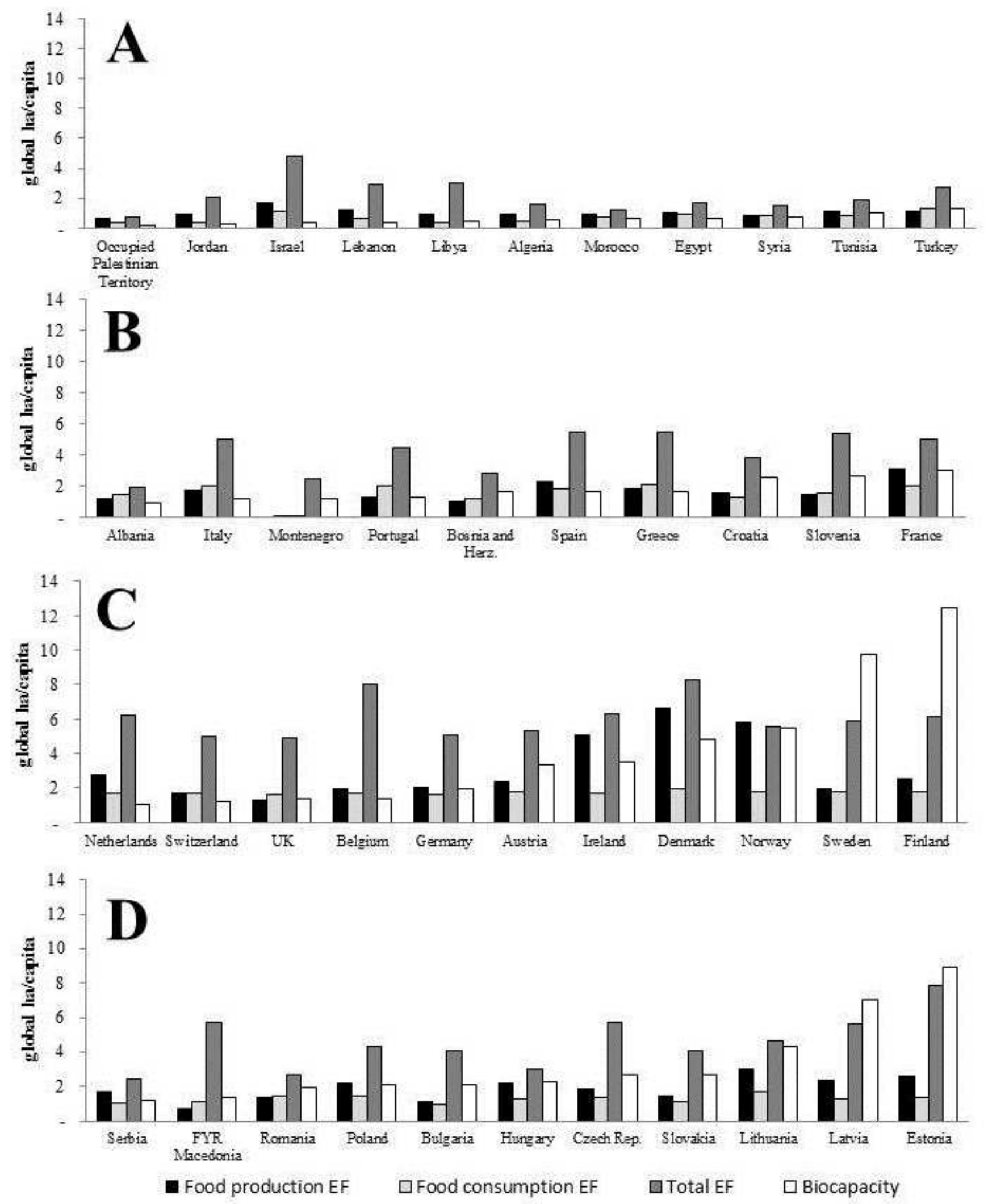

Figure 5. Ecological footprint (EF) Ecological footprint (year 2007) associated to food production (black bars), food consumption (light grey bars), total EF (dark grey bars) biocapacity (white bars) for the four country clusters ( $A=$ Mediterranean European (ME) countries; $B=$ Other Mediterranean $(O M)$ countries; $C=$ Northern European (NE) countries; $D=$ Eastern European (EE) countries). 

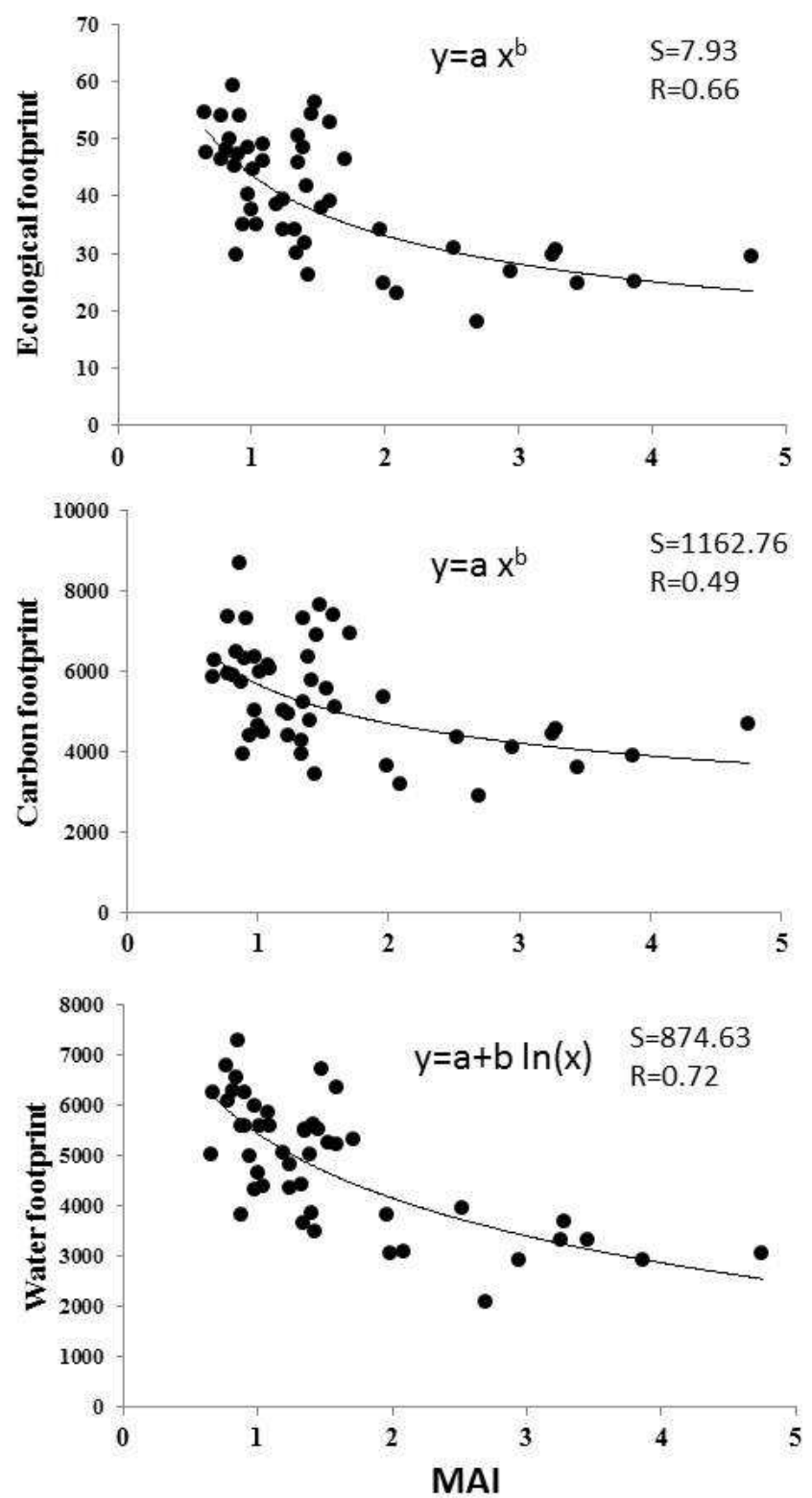

Figure 6. Relationship between food consumption footprints and MAI. Relationship between food consumption ecological footprint (A), carbon footprint $(B)$ and water footprint $(C)$ with Mediterranean Adequacy Index (MAI) in all the considered countries for the year 2007. Coefficient a and $b$ in the equations described are respectively: $a=44.43$ and $b=-0.004$ for ecological footprint; $a=5811.3$ and $b=-0.26$ for carbon footprint; $a=5446.5$ and $b=-$ 1853.99 for water footprint.

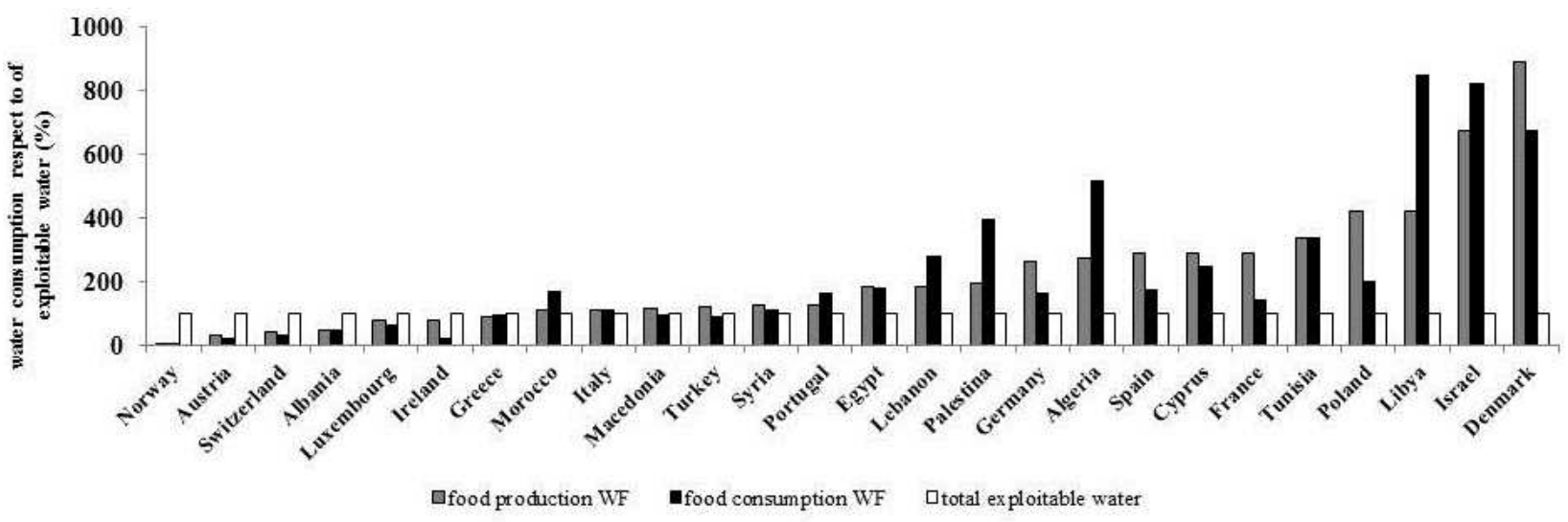

Figure 7. Water footprint. Food production water footprint (gray bars) and food consumption water footprint (black bars) related to total exploitable water (white bars) for the years 2007, only in countries with available data. 
The evidence that water consumption is higher than exploitable water for great part of the countries is likely due to the abandon of the Mediterranean healthy diet principles. Returning to the previous habits can be reflected in a strong reduction of water consumption.

Recently, the impacts of reducing meat and animal products consumption on the reactive nitrogen cycle and nitrogen compounds emissions has been analysed (Westhoek et al, in press). A practical way to replace red meats has been suggested by Smil (2002) who discussed the inclusion of protein extenders from plant origin for replacing red meat for hamburgers. McMichael et al. (2007) estimated, as a working global target, a $10 \%$ reduction in the current global average meat consumption of 100 $\mathrm{g} /$ person/day.

Despite the huge amount of evidences showing that the Mediterranean diet is healthy (Trichopoulou et al. 2007; Kastorini et al. 2011; Esposito et al. 2006; Toobert et al. 2007; Buckland et al. 2008), dietary changes are not yet properly taken into account for the contribution that could lead to the improvement of public health and to the sustainability of the environmental resources (CarlssonKanyama and Gonzalez 2009).

A change in dietary habits toward a Mediterranean diet (or in general vegetable-based, high MAI level diet) is suitable and recommended, mostly for those countries having a food consumption footprint exceeding their biocapacity. In fact, it could result in a reduction of ecological footprint below the threshold of the biocapacity of a given country. The production of fruits and vegetables and other vegetable-based foods, basis of a high MAI diet, is less resource-intensive than the production of meat and other non-Mediterranean food like dairy and animal derived fat (Macdiarmid et al., 2012, Duchin 2005).

A diet composed of locally and regionally produced foods is to be preferred because it reduces the energy costs and pollution associated with transportation (Duchin 2005) and results to be less expensive and therefore more affordable to a large public. Avoiding excess energy intake is healthier, and food requires less resources (Duchin 2005).

Concerning the real possibility to change the personal behaviours, informative campaigns have demonstrated that sharp changes in life-styles can be achieved relatively quickly (Duchin 2005). As an example, the proportion of adult smokers in the U.S. dropped from $42 \%$ in 1965 to $19 \%$ in 2010 (Centres for Disease Control and Prevention 2011) as a result of antismoking campaigns, labelling requirements, and mass communication of compelling scientific evidence of the ill effects of smoking on health. The same approach should be done for changing dietary habits, improving food education initiatives in the schools and addressing the communications to families, ameliorate labelling requirements on food items and mass communication of scientific evidences of the negative impacts of wrong dietary habits on health and the environment.

\section{Conclusions}

The adherence to Mediterranean diet (MAI) is decreasing in all the Mediterranean countries, both European or not-European, even if with different rates. The MAI of Mediterranean European countries is actually more close to values observed in northern European ones, around the value of 1, whilst higher levels are maintained in nonEuropean Mediterranean countries, around the value of 3 . The MAI is shown to be linked to human health. In fact, it is negatively related to the colorectal cancer incidence, that is significantly related to the consumption of animal protein In the same time, ecological, carbon and water footprints are importantly affected by MAI values, with remarkable effects on the human health. Thus, MAI can be considered an important indicator for evaluating the impacts on the environment health derived from the food consumption. These results support the hypothesis concerning the Mediterranean diet to be a win-win policy, due to its beneficial effects on the human and environment health.

\section{Acknowledgements}

This work was made possible thanks to the good cooperation and harmony between the authors. We would like to thank the Expert Panel on Nitrogen and Food, chaired by Henk Westhoek (PBL, The Netherland), on behalf of the Task Force on Reactive Nitrogen for helpful discussion on the obtained results.

\section{References}

[1] Alberti, A., Fruttini, D., Fidanza, F., 2009. The Mediterranean adequacy index: further confirming results of validity. Nutrition, Metabolism and Cardiovascular Diseases $19,61-66$

[2] Alberti-Fidanza, A., Fidanza, F., 2004. Mediterranean adequacy index of Italian diets. Public Health Nutrition 7 , 37-941.

[3] Alberti-Fidanza, A., Fidanza, F., Chiuchiu, M.P., Verducci, G., Fruttini, D., 1999. Dietary studies on two rural Italian population groups of the Seven Countries Study. 3. Trend of food and nutrient intake from 1960 to 1991. European Journal of Clinical Nutrition 53, 854-860.

[4] AQUASTAT (2011). Main country database. www.fao.org/nr/water/aquastat/main/index.stm, visit January 2011.

[5] Bates, B., Lennox, A., Bates, C., Swan. G.,2011 National Diet and Nutrition Survey: headline results from years 1 and 2 (combined) of the rolling programme 2008/09 - 2009/10. Department of Health Available at http://www.dh.gov.uk/en/Publicationsandstatistics/Publicatio ns/PublicationsStatistics/DH_128166.

[6] Bogani, P., Galli, C., Villa, M., Visioli, F., 2007. Postprandial anti-inflammatory and antioxidant effects of extra virgin olive oil, Atherosclerosis 190, 181-186. 
[7] Borucke, M.. Moore, D., Cranston, G., Gracey, K., Iha, K., Larson, J., Lazarus, E., Morales, J.C., Wackernagel, M., Galli, A., 2013.Accounting for demand and supply of the biosphere's regenerative capacity: The National Footprint Accounts' underlying methodology and framework, Ecological Indicators 24, 518-533.

[8] Buchner, B., Fischler, C., Fitoussi, J.P., Monti, M., Riccardi, G., Ricordi, C., et al., 2009. In Doppia Piramide: alimentazione sana per le persone, sostenibile per il pianeta (eds Barilla center for food and nutrition).

[9] Buckland, G., Bach, A., Serra-Majem, L., 2008.Obesity and the Mediterranean diet: a systematic review of observational and intervention studies Obesity Reviews 9, 582-93.

[10] Carlsson-Kanyama, A., Ekstrom, M.P., Shanahan, H., 2003.Food and life cycle energy inputs: consequences of diet and ways to increase efficiency. Ecological Economics 44, 293-307.

[11] Carlsson-Kanyama, A., Gonzalez, A.D., 2009.Potential contributions of food consumption patterns to climate change. The American Journal of clinical nutrition89, 1704S-1709S.

[12] Carlsson-Kanyama, A., 1998.Climate change and dietary choices: how can emissions of greenhouse gases from food consumption be reduced? Food Policy23, 277-293.

[13] Centers for Disease Control and Prevention (CDCP), 2011.Hyattsville, MD: National Center for Health Statistics. Available:

http://www.cdc.gov/tobacco/data_statistics/fact_sheets/adult _data/cig_smoking/ index.htm. [accessed 12 September 2011].

[14] Chan, D.S., Lau, R., Aune, D., Veira, R., Greenwood, D.C., Kampman, E., et al.,2011. Red and processed meat and colorectal cancer incidence: meta-analysis of prospective studies. PLoS One 6, e20456.

[15] Chrysohoou, C., Panagiotakos, D.B., Pitsavos, C., Das, U.N., Stefanadis, C., 2004. Adherence to the Mediterranean diet attenuates inflammation and coagulation process in healthy adults: the ATTICA study. Journal of the American College of Cardiology44, 152-158.

[16] Collins, A., Fairchild, R., 2007. Sustainable food consumption at a Sub-national level: an ecological footprint, nutritional and economic analysis. Journal of environmental policy and planning9, 5-38.

[17] Corbalán, M.D., Morales, E.M., Canteras, M., Espallardo, A., Hernández, T., Garaulet, M., 2009. Effectiveness of cognitive-behavioural therapy based on the Mediterranean diet for the treatment of obesity. Nutrition $25,861-869$.

[18] Dernini, S., 2006.Towards the advancement of the Mediterranean food cultures. Public Health Nutrition 9, 103-104.

[19] Duchin, F., 2005.Sustainable consumption of food: a framework for analysing scenarios about changes in diets. Journal of Industrial Ecology9, 99-114.

[20] Engstrom, R., Wadeskog, A., Finnveden, G.,2007. Environmental assessment of Swedish agriculture. Ecological Economics 60, 550-563

[21] Esposito, K., Ciotola, M., Giugliano, D., 2006.
Mediterranean diet, endothelial function and vascular inflammatory markers. Public Health Nutrition 9, 10731076.

[22] ETAP, 2007. The Carbon Trust Helps UK Businesses Reduce their Environmental Impact, Press Release

[23] FAO (2011). Food and Agriculture Organization of United Nations. Statistical data Food Balance Sheet.

[24] Figueiredo J., Hsu L., White, E. Chan, A. Zanke B., Potter, J. Casey, G. Hutter, C. Brenner, H. Caan, B. Chang-Claude, J. Gallinger, S. Hayes, R. Hudson, T. Le Marchand, L. Newcomb, P. Schoen, R. Slattery, M. Peters, U. Genomewide analyses highlights gene interaction with processed meat and vegetable intake for colorectal cancer risk, The American Society of Human Genetics, in press.

[25] Galeone, C., Talamini, R., Levi, F., Pelucchi, C., Negri, E., Giacosa, A., et al.,2006. Fried foods, olive oil and colorectal cancer. Annals of oncology 18, 36-39.

[26] Galli, A., Wiedmann, T., Ercin, E., Knoblauch, D., Ewing, B., Giljum, S., 2012.Integrating Ecological, Carbon and Water footprint into a "Footprint Family" of indicators: Definition and role in tracking human pressure on the planet Ecol. Indic. 16, 100-112.

[27] Gingras, D.,Béliveau, R., 2011. Colorectal cancer prevention through dietary and lifestyle modifications. Cancer Microenvironment 4, 133-139.

[28] GFN (2011). Global Footprint network. Advancing the Science of Sustainability, www.footprintnetwork.org, visit January 2011

[29] Goulet, J., Lapointe, A., Lamarche, B., Lemieux, S., 2007. Effect of a nutritional intervention promoting the Mediterranean food pattern on anthropometric profile in healthy women from the Quebec city metropolitan area. European Journal of Clinical Nutrition 61, 1293-1300.

[30] Hoekstra, A.Y., (ed.), 2003.Virtual water trade: Proceedings of the International Expert Meeting on Virtual Water Trade, Delft, The Netherlands, 12-13 December 2002, Value of Water Research Report Series No.12, UNESCO-IHE, Delft, The Netherlands, www.waterfootprint.org/Reports/Report12.pdf

[31] Hoekstra, A.Y., Chapagain, A.K., Aldaya, M.M., Mekonnen, M.M., 2011. The water footprint assessment manual: Setting the global standard, ISBN: 978-1-84971-279-8 Hardcover, 224 pages

[32] IEA, International Energy Agency, 2009. $\mathrm{CO}_{2}$ Emissions from Fuel Combustion 2009 - Highlights " $\mathrm{CO}_{2}$ emissions / population"(2007).

[33] Kastorini, C.M., Milionis, H.J., Esposito, K., Giugliano, D., Goudevenos, J.A., Panagiotakos, D.B., 2011. The Effect of Mediterranean Diet on Metabolic Syndrome and its Components. A Meta-Analysis of 50 Studies and 534,906 Individuals. Journal of the American College of Cardiology 57, 1299-1313.

[34] Kerney, J., 2010. Food consumption trends and drivers Philosophical Transactions of the Royal Society B 365, 2793-2807

[35] Keys, A., 1980.Seven Countries: a multivariate analysis of death and coronary heart disease. London: Harvard University Press. 
[36] Kouris-Blazos, A.K., Gnardellis, C., Wahlqvist, M.L., Trichopoulos, D., Lukito, W., Trichopoulou, A., 1999. Are the advantages of the Mediterranean diet transferable to other populations? A cohort study in Melbourne, Australia. British Journal of Nutrition 82, 57-61.

[37] Larsson, S.C.,Wolk, A., 2006. Meat consumption and risk of colorectal cancer: a meta-analysis of prospective studies. International Journal of Cancer 119, 2657-2664.

[38] Lazarou, C., Panagiotakos, D.B., Matalas, A.L., 2009. Lifestyle factors are determinants of children's blood pressure levels: the CYKIDS study blood pressure risk factors in children. Journal of Human Hypertension 23, 456463.

[39] Macdiarmid, J.I., Kyle, J., Horgan, G.W., Loe, J., Fyfe, C., Johnstone, A., McNeill, G., 2012. Sustainable diets for the future: can we contribute to reducing greenhouse gas emissions by eating a healthy diet? Am J Clinical Nutrition 96, 632-9.

[40] McMichael, A., Powles, J.W., Butler, C.D., Uauy, R.,2007.Food, livestock production, energy, climate change, and health. Lancet 370, 1253-63.

[41] Mekonnen, M.M., Hoekstra, A.Y., 2011. In National water footprint accounts: the green, blue and grey water footprint of production and consumption, eds Value of Water Research Report Series n. 50, UNESCO-IHE Institute for Water Education (Delf, the Netherlands).

[42] Mendez, M.A., Popkin, B.M., Jakszyn, P., Berenguer, A., Tormo, M.J., Sanchéz, M.J.,et al., 2006. Adherence to a Mediterranean diet is associated with reduced 3-year incidence of obesity. The Journal of Nutrition1 36, 2934 2938.

[43] Osler, M.,Schroll, M.,1997.Diet and mortality in a cohort of elderly people in a North European community. International Journal of Epidemiology 26, 155-159.

[44] Owen, R.W., Giacosa, A., Hull, W.E., Haubner, R., Spiegelhalder, B., Bartsch, H., 2000. The antioxidant/anticancer potential of phenolic compounds isolated from olive oil. European Journal of Cancer 36, $1235-1247$.

[45] Panagiotakos, D.B., Chrysohoou, C., Pitsavos, C., Stefanadis, C., 2006. Association between prevalence of obesity and adherence to the Mediterranean diet: the ATTICA study. Nutrition22, 449-456.

[46] Rees, W.E., 1992. Ecological footprints and appropriated carrying capacity: what urban economics leaves out. Environment and Urbanisation 4, 121-130.

[47] Reguant-Aleix, J., Arbore, M.R., Bach-Faig, A., SerraMajem, L.,2009.Mediterranean Heritage: an intangible cultural heritage. Public Health Nutrition 12, 1591-1594.

[48] Rotondi, A., Lapucci, C., 2010. Nutritional properties of extra-virgin olive oils from the Emilia-Romagna region: profiles of phenols, vitamins and fatty acids in Olives and olive oil in health and disease prevention, eds Preedy VR, Watson R (Academy Press), pp 725-733.

[49] Schlich, E.H., Fleissner, U., 2005.The ecology of scale: assessment of regional energy turnover and comparison with global food. The International Journal of Life Cycle Assessment10, 219-223.
[50] Shai, I., Schwarzfuchs, D., Henkin, Y., Shahar, D.R., Witkow, S., Greenberg, I., et al., 2008. Weight loss with a low-carbohydrate, Mediterranean, or low-fat diet. The New England Journal of Medicine 359, 229-241.

[51] Smil, V., 2002. Worldwide transformation of diets, burden of meat production and opportunities for novel food proteins. Enzyme and Microbial Technology 30, 305-11.

[52] Sofi, F., Cesari, F., Abbate, R., Gensini, G.F., Casini, A., 2008. Adherence to Mediterranean diet and health status: meta-analysis. British Medical Journal, 337

[53] Toobert, D.J., Glasgow, R.E., Strycker, L.A., Barrera. M. Jr, Ritzwoller, D.P., Weidner, G., 2007. Long-term effects of the Mediterranean lifestyle program: a randomized clinical trial for postmenopausal women with type 2 diabetes. International Journal of Behavioral Nutrition and Physical Activity 4, 1 .

[54] Trichopoulou, A., Kouris-Blazos, A., Wahlqvist, M.L., Gnardellis, C., Lagiou, P., Polychronopoulos, E.,et al., 1995. Diet and overall survival in elderly people. British Medical Journal 311, 1457-1460.

[55] Trichopoulou, A., Psaltopoulou, T., Orfanos, P., Hsieh, C.C., Trichopoulos, D.,2007.Low-carbohydrate-high-protein diet and long-term survival in a general population cohort. European Journal of Clinical Nutrition 61, 575-581.

[56] van Meijl, H., van Rheenen T., Tabeau A., Eickhout B. 2006. The impact of different policy environments on agricultural land use in Europe. Agriculture, Ecosystems \& Environment. $114,121-38$.

[57] Wackernagel, M, Rees, W.E., 1996. Our Ecological Footprint: Reducing Human Impact on the Earth. New Society Publishers, Gabriola Island, British Columbia, Canada. German edition with updated data, 1997. Birkhäuser, Basel, 1997.

[58] Wackernagel, M., and Yount, J.D.,1998. The ecological footprint: an indicator of progress toward regional sustainability. Environmental Monitoring and Assessment $51,511-529$.

[59] Wackernagel, M., White, S., Moran, D., 2004.Using Ecological Footprint accounts: from analysis to applications. Int. J. Environment and Sustainable Development 3, 293315 .

[60] Westhoek, H., Lesschen, J.P., Rood, T., Wagner, S. De Marco, A., Murphy-Bokern, D., Leip, A., van Grinsven, H., Sutton, M.A., Oenema, O., Food choices, health and environment: effects of cutting Europe's meat and dairy intake. Global environmental Change, in press.

[61] Westhoek, H., Rood, T., van de Berg, M., Janse, J., Nijdam, D., Reudink, M., et al., 2011. In The protein puzzle: the consumption and production of meat, dairy and fish in the European Union, eds PBL Netherlands Environmental Assessment Agency (The Hague, Netherland).

[62] Wiedmann, T., and Minx, J., 2008. A Definition of 'Carbon Footprint'. In: C. C. Pertsova, Ecological Economics Research Trends: Chapter 1, pp. 1-11, Nova Science Publishers, Hauppauge NY, USA

[63] Wiedmann, T., Barrett, J.,2010. A Review of the Ecological Footprint Indicator-Perceptions and Methods. Sustainability 2, 1645-1693. 
[64] Wiedmann, T., Lenzen, M.,2007. On the Conversion between local and global hectares in Ecological Footprint analysis. Ecological Economics 60, 673-677.
[65] WHO, World Health Organization 2008 "Protein and Amino Acid Requirements in Human Nutrition”. 